\author{
Krzysztof Jarzęcki \\ https://doi.org/10.26485/AAL/2021/67/10
}

\title{
SOME REFLECTIONS ON FAUSTINA'S THE YOUNGER COINS
}

Martin Beckmann, Faustina the Younger: Coinage, Portraits, and Public Image, Numismatic Studies 43, American Numismatic Society, New York 2021, 205 pp.

The phenomenon of the production of coins with portraits of female members of Roman imperial families is still very little recognized. Despite the considerable existing literature on the subject, such basic questions as their detailed chronology, and even the motive behind their issue (in the case coins struck by males these are usually clear and long-resolved issues) remain without satisfactory answers. Consequently, the cognitive potential of the quite popular archaeological source constituted by coins, is little used for answering such important issues as, for example, the role of the Roman empresses. An interesting voice in the study of the coins of Augustae is the work by Martin Beckmann on coins with the portrait of Faustina the Younger.

The work consists of an Introduction: Faustina the Younger: Coinage, Portraits, and Public Image (p. 1-5) and the following chapters: 1. Material and Methodology (pp. 7-22), 2. VENVS GENETRIX: Faustina's First Child: Portrait Type 1 (pp. 23-34), 3. CONCORDIA: The Ideal of the Imperial Marriage: Portrait Types 2-5 (pp. 35-47), 4. FAVSTINA AVGVSTA: Portrait Types 5-10 (pp. 49-66), 5. Portraits: Concepts and Process (pp. 67-74), 6. A New Typology of Faustina's Portraits (pp. 75-91), 7. Message and Meaning in the Portraits of Faustina (pp. 93-103). The book also includes a Conclusion: The Public Image of Faustina (p. 105-109), Appendix I: Faustina's Children (pp. 111-113), and Appendix 2: Relative Proportions of Reverse Types in AV and AR (pp. 115-117). The Bibliography (pp. 119-123) consists of 83 items only. The most recent works cited are Römische Medaillons II... by P. F. Mittag (2019) and The Image of Political Power... by N. T. Elkins (2017). The work also includes Die Catalogue, Part I: Aurei of Faustina II under Antoninus Pius (pp. 125-142), Die Catalogue, Part 2: Aurei of Faustina II under Marcus Aurelius (pp. 143-156), Key to the Die Link Charts (pp. 157-166), List of Die Illustrations (pp. 167-172) includes 352 items. At the end of the work there are plates with photographs of the coins in chronological order (pp. 173-203). The photos of the coins enlarged are of varying quality, some of them extremely poor (e. g. ff13, p. 180), and this is not because they are from an old publication. At the end (p. 205) there is a short Index.

As we can read in the Introduction: The coinage of Faustina the Younger is rich in original iconography and long duration, but its chronology and the relationships between its various types remain unclear. This study seeks to remedy this situation by employing the methodology of die analysis to create a new and firm chronology for Faustina's coinage. The results make it possible to establish an authoritative typology for Faustina's portraiture and to show the precise relationship between the diverse obverse and reverse types. ${ }^{1}$ After establishing the chronology of the portraits and dies, the author attempts the following interpretation. What was the purpose of these images? Who chose them? To what end? What can we learn from them? ${ }^{2}$ and finally Would Faustina herself have had any influence over was depicted on 'her' coinage?. ${ }^{3}$ The author writes that Die analysis seeks to reconstruct, as far as possible, the exact sequence of use of dies in the mint. ${ }^{4}$ For research he used 681 gold coins from the contents of public collections, published archaeological finds, and trade catalogues. ${ }^{5} \mathrm{He}$ calculated that they are struck by 134 obverse and 197 reverse dies, and their original number as 162 obverse and 257 reverse dies. It is a pity that he did not compare these results with the research that A. M. Woodward

\footnotetext{
Beckmann M. 2021. Faustina..., p. 1.

Ibid., p. 3.

Ibid., p. 11.

Ibid., p. 13.

Ibid., p. 16.
} 
carried out for the coins of Pertinax ${ }^{6}$ and Didius Julianus. ${ }^{7}$ It should be added that the book deals primarily with gold coins, conventionally called the aurei, and those struck during Faustina's lifetime. According to the author 'it appears almost certain', that the issue of Faustina's gold coins had begun 'in December 147 or very shortly thereafter'. These are the types: VENERI GENETRICI, IVNONI LVCINAE, and LAETITAE PVBLICAE. ${ }^{8}$ The author refers to Sabina's denarius with the legend of VENERI GENETRICI, although he admits that the exact date is not known, but it falls somewhere in the 130s. ${ }^{9}$ The only conclusion that can be drawn from this example is that a given type appeared in Sabina's coinage and that it was not one of the earliest issues of hers. One could refer to literature, e.g. works by R. Abdy. ${ }^{10}$ Regarding the LAETITIA type coins, I can add that the results of my research indicate that in terms of metrology Faustina's denarii type LAETITIAE PVBLICAE (RIC 506) are very similar to the Antoninus Pius denarii with Tranquilitas from the years $150-151 \mathrm{AD}$, perhaps they are their 'twin emission'. In the same years the aurei of Antoninus Pius with Ceres and Proserpina and legend LAETITIA COS IIII (RIC 199) were struck. However, I do not accuse M. Beckman that he does not know this work, given that it was published at the end of 2019 and is written in Polish. ${ }^{11}$

An important and interesting part of the work under review is the fragment about the typology of Faustina's portraits on coins. Beckmann distinguishes 10 types, and gives a chronology, usually relative. The considerations are illustrated with diagrams connecting the coin dies (die link charts). One of them ${ }^{12}$ shows when Faustina's filiation would have been dropped from the coin legends. The fact that this happened before the death of Antoninus Pius was already known before World War II. Beckmann's merit is the visualization of this event. According to the author, this happened in 157. An interesting argument in the discussion of the chronology of this event is not only the hoard

6 Woodward A. M. 1957. The coinage of Pertinax, The Numismatic Chronicle, 17, 84-96.

7 Woodward A. M. 1961. The coinage of Didius Julianus and his family, The Numismatic Chronicle, 71-90, cf. Jarzęcki K. 2018. Mennica rzymska za Didiusza Juliana, Warszawski Pamiętnik Numizmatyczny, 6, 11-32.

8 Beckmann M. 2021. Faustina..., p. 27.

Ibid., p. 28.

10 Abdy R. 2014, Chronology of Sabina's coinage at the Roman mint, Revue Numismatique, 174, 73-91.

11 Jarzęcki K. 2019. System..., p. 162.

12 Beckmann M. 2021. Faustina..., p. 52. of aurei from Egypt but also a large shipment of medium bronze to Britain in AD 155, as shown by coin finds at Bath. The core of this shipment was the Britannia type of Antoninus Pius, which is almost never found outside of Britain. ${ }^{13}$ The author could quote the work of N. T. Elkins on the coins of Nerva with Neptune ${ }^{14}$ to show that it was not an isolated case, and analyses of such finds can also be useful in studies of the coins of Augustae. The author devotes some attention ${ }^{15}$ to the die production process, focusing on the strictly technological side, unfortunately without going into the organization of production. In another part of the book, he only mentioned, that one of the possible explanations for one of the phenomena described is that some engravers made dies used for gold coins and others bronze. ${ }^{16}$ An interesting, although a long-known observation which was used by M. Beckmann when analyzing Faustina's coins, is the way the legend is placed on the coin, i.e. the so-called all-around legend [...] with no break above the portrait or reverse type. ${ }^{17}$ This manner is dated between 161-163. ${ }^{18}$ Writing about the style of Faustina's portraits on her latest coins, he compares them to the representations on Lucilla's coins. While the mere fact that such comparisons can be made, obviously, should be commended, it is regrettably the only such comparison made in the entire book. The information about the chronology of Lucilla's coins, brought to an end in 169, when her husband Lucius Verus died without any explanation, is already very outdated (cf. BMC and descriptions in trade catalogues). It is a pity that the author did not refer to Lucilla's coinage when writing about aurei bearing the legend FAVSTINAE AVGVSTAE on the obverse and MATER CASTRORVM on the reverse (one of the two known specimens, so far unpublished, was found in Poland). After all, Lucilla's golden quinarius with a similar legend is known from the collection of the British Museum and from RIC. ${ }^{19}$ About the posthumous coinage of Faustina, the author writes, that it was perhaps concluded within a year of Faustina's death. ${ }^{20}$ Where did he get this

13 Ibid., p. 56.

14 Elkins N. T. 2019. The Circulation of Nerva's Neptune Coins in Britannia [in:] S. Krmnicek, J. Chameroy ed., Money Matters. Coin Finds and Ancient Coin Use, Bonn, 75-81.

15 Beckmann M. 2021. Faustina..., p. 72-74.

16 Ibid., p. 34.

17 Ibid., p. 58

18 Ibid., p. 58, 63.

19 Inv. no. 2868, RIC III 776.

20 Beckmann M. 2021. Faustina..., p. 66. 
information from? An important observation is that 'Types 5 and 6 were used at the same time', and the same applies to Types 7,8 , and $9 .{ }^{21}$ It is a pity that after obtaining such results, the author did not try to analyze dies of coins made of other metals, coin finds, etc. If such an observation is correct, it seems that both in the coinage of Faustina and other female members of the imperial families it was probably an exception that can be explained by the organization of the mint. Perhaps the time of popularity of these types coincides with the time of reducing the production of coins with portraits of empresses to such that the dies were not fully exploited. Similar conclusions about the reduction in the production of women's coins during this period can be drawn from the analysis of the Lucilla coins. The author himself writes that this may be the result of an error by the engraver who chose an incorrect model (presumably an earlier coin $)^{22}$ (p. 103).

One of the results of M. Beckmann's work is a new typology of coins of Faustina II. Compared to K. Fittschen's typology from 1982, covering 9 types, the new typology includes 10 . The changes result both from the reclassification of some representations and the introduction of a previously undescribed Type 4, present on one aureus and one medallion.

In the following parts of the work, Beckmann presents Fittschen's thesis that ...each new type (defined primarily by a new arrangement of the hair) was created when Faustina gave birth to a child (or children, in the case of twins ${ }^{23}$ and that a portrait type was the equivalent of a special honour created for an emperor (or empress) on a noteworthy occasion. ${ }^{24}$ Beckmann concludes that the generally accepted model for their creation is wrong and ... a new portrait was created when it was clear that the extant portrait no longer reflected the actual appearance of the emperor. A theory based on the concept that portrait types were created mainly to keep the image of the emperor or empress current does not exclude the potential influence of ideological factors $^{25}$ (p. 101). An interesting observation is that Faustina herself made changes in her personal appearance, at various times throughout her life and for different reasons, unknown to us. ${ }^{26}$ So these were new portraits not so much created to honor Faustina, but inspired by her. Only in one case (portrait

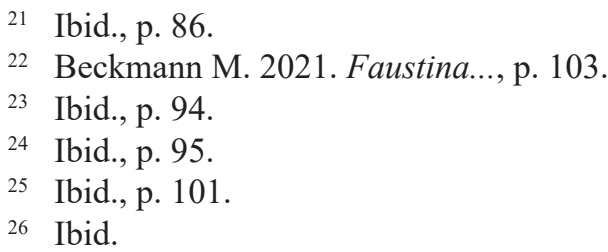

Type 2) is a connection to a birth in the imperial family absolutely clear, revealed by the synchronous appearance of a birth-associated reverse type and the new portrait type. ${ }^{27}$ The birth of the first child was of particular importance to a newly-established dynastic system, triggering Faustina's promotion to Augusta and the initiation of coinage in her name while at the same time signalling the end of the adoptive tradition. ${ }^{28}$ Beckmann's concept of the mechanism of creating new portraits is convincing. It is just a pity that the author did not show it in the context of other empresses. One example which could be given here is the coinage of Crispina. The change of her hairstyle seems to coincide with the assumption of independent rule by her husband Commodus in $180 \mathrm{AD}$. Crispina then adopted a hairstyle similar to the last hairstyle of Faustina II. ${ }^{29}$ Lucilla also decided to take a similar step. This may be a material manifestation of the competition between these women, known from written sources. The subject of competition would be to be seen as the successor to the diva Faustina. The death of Marcus Aurelius may have fueled this competition. Importantly, Crispina and Lucilla departed from this hairstyle for a different one, identical in both cases. ${ }^{30}$

The general presentation of Beckmann's work can be concluded with the statement that Its greatest advantages are the development of a chronology of the obverses and reverses of aurei, tables showing the connections of dies, and the presentation of arguments undermining the concept of creating new portraits according to Fittschen. There are sufficient reasons to read this book. The book under current review, however, also contains errors, questionable statements and understatements.

One such passage is a reference to the Reka Devnia hoard of denarii. This is an exceptionally valuable archaeological source, but like any other source, it requires critical treatment. One has to ask how this hoard was formed and what processes it reflects. Can the exceptionally large number of coins making up this find, be considered a direct reflection of the production of specific types of coins at the Rome mint, as M. Beckmann has done? (p. 8). This is rather doubtful. It is more likely that this hoard mirrors the structure of the

27 Ibid., p. 106

28 Ibid., p. 105

29 Jarzęcki K. 2015a. Mennictwo cesarzowej Kryspiny, Biuletyn Numizmatyczny, 3 (379), p. 172.

30 Jarzęcki K. 2015b. Lucylla w świetle źródet numizmatycznych [in:] Pieniądz a propaganda: wspólne dziedzictwo Europy. Studia i materiały, red. K. Filipow, Warszawa-Augustów, p. 44. 
money (denarii) in circulation on the periphery of the Imperium Romanum..$^{31}$ In his book, the author himself mentioned a similar phenomenon in the case of the coins of Antoninus Pius depicting Britania, the finds of which are known mainly from Britain. This phenomenon is well described in one book on Nerva's coinage, quoted by Beckmann. ${ }^{32}$ An example of the fact that the hoard of Reka Devnia cannot be treated as a direct reflection of the production of the mint in Rome are the posthumous denarii of Faustina the Elder of the type PVELLAE FAVSTINIANAE, which, as indicated by the information provided by trade catalogues, are more common than this hoard would suggest. ${ }^{33}$ If we consider the hypothesis that Roman coins in the 2 nd century were minted with a view to specific expenses (in her case many arguments could be cited, including the results of research by the same author ${ }^{34}$ and often try to identify these purposes) it seems natural to ask if coins bearing the portrait of the empress could be minted with the idea of paying sums to soldiers stationed at the border for their help. If not, if coins with portraits of empresses were minted to cover the expenses of the empresses, from a certain amount of metal that was allocated for that purpose, it must also be assumed that the coins bearing the portraits of empresses which made their way to the soldiers stationed on the limes were already mixed up with other issues. Bearing this in mind it should be concluded that any inference about the proportion of coins in circulation with the portraits of the Augustae derived from the Reka Devnia hoard cannot yield reliable results. Any such inferences should have been based on a larger number of hoards, ${ }^{35}$ preferably drawn from various parts of the Roman Empire.

31 Cf. Jarzęcki K. 2019. Struktura wagowa denarów rzymskich z lat 138-161, Acta Archaeologica Lodziensia, $65,160$.

32 Elkins N. T. 2017. The Image of Political Power in the Reign of Nerva, AD 96-98, Oxford.

33 Jarzęcki K. 2019. Struktura..., p. 160.

34 Beckmann M. 2015. Trajan's Restored Coinage: Volume, Value and Purpose, Revue Belgue de Numismatique et Sigillographie, CLXVI, 311-324; Beckmann M. 2017. The restoration of Mark Antonyss legionary denarii by Marcus Aurelius and Lucius Verus, The Numismatic Chronicle, 177, 135-147; one such argument may be the coins commemorating the marriage of Marcus Aurelius and Faustina the Younger, see Beckmann M, 2021. Faustina ..., p. 24.

35 Cf. Dunkan-Jones R. P. 2006. Crispina and the Coinage of the Empresses, The Numismatic Chronicle, vol. 166, 223-228.
M. Beckmann has written: The most common coin in circulation was the denarius. ${ }^{36}$ It is a pity that he did not provide the source for this information. If we look at databases of coins currently being traded, we can get the following impression. For example, a few numbers resulting from my queries on acsearch.info:

\begin{tabular}{|c|c|c|c|c|c|}
\hline & aurei & denarii & erces & ndii & asses \\
\hline Nerva & 107 & 845 & 137 & 63 & 99 \\
\hline Trajan & 520 & 898 & 170 & 63 & 36 \\
\hline Hadrianus & 650 & 842 & 125 & 225 & 102 \\
\hline Lucius Verus & 105 & 372 & 141 & 20 & 21 \\
\hline
\end{tabular}

It should be remembered, however, that the numbers given above reflect not so much money in circulation as the total volume of coin production of a given issuer during the entire period of his reign. It is also worth recalling that, as is well known, coins of different denominations had different functions: aurei and denarii were used to carry out major financial operations and hoarding, while copper alloy coins dominated in everyday money circulation. As can be seen, silver and gold coins were minted in the greatest quantity, but they were the rarest encountered in everyday life. This can be seen very clearly in the example of finds from Pompeii (very well elaborated by Giacomo Pardini) or Rome, from the so-called sottosuolo urbano (SSU). It is also possible that in the Central European Barbaricum, there were many more coins made of copper alloys than appears from the finds, but they were treated by the inhabitants of these lands as a source of raw material for the production of other items. Coin issuers and users were probably well aware that different denominations had different functions (a famous example is the painting in the villa of Iulia Felix in Pompeii), so this fact was taken into account in their propaganda activities. It is no coincidence that Antoninus Pius's Britania type is usually found in Britain. ${ }^{37}$ It is no coincidence that Pius' series of coins with the provinces were minted in bronze. It is no coincidence that the coins of Mark Antony restored by Aurelius and Verus were silver denarii because these were coins intended for soldiers. ${ }^{38}$ These examples could be multiplied many times over. Being aware of

36 Beckmann M. 2021. Faustina..., p. 7.

37 Cf. Beckmann M. 2021. Faustina..., 56.

38 Beckmann M. 2017. The Restoration of Mark Antony's Legionary Denarii by Marcus Aurelius and Lucius Verus, The Numismatic Chronicle, 177, 135-147. 
these facts, we can see that M. Beckmann's book deals with propaganda activities carried out with the help of gold coins, aimed at rich people, certainly not at simple soldiers or the poor. Coming back to the role of denarii, it would be much better to say: The silver denarius is generally considered to be the base of the Roman monetary system... ${ }^{39}$

M. Beckmann refers to Roman coins of other issuers, although far too little in my opinion. The 'great absentees' include, inter alia, joint issues of ases of Antoninus Pius and Faustina II (BMC 1843) and Marcus Aurelius and Faustina II (RIC 1366). It is also a pity that the author did not refer to provincial coins, especially from Alexandria, which contain annual dates, and on which Faustina is portrayed with various hairstyles. The author could also cite the example of Sabina, depicted both on imperial and provincial coins with a few hairstyles. The more so that in recent years this topic has received several studies (unfortunately, not always satisfactory)..$^{40}$

This is not the end of the list of works, apparently obviously useful when dealing with the subject under discussion, which, however, the author did not make use of for some reason. An example is the work of the Italian numismatist Alessio Busseni. ${ }^{41}$ It is an amateur work, which does not claim to correctly resolve the issues raised, ${ }^{42}$ but it is worth getting acquainted with it when writing about the coins of Faustina II. Here are a few examples that might be worth mentioning: $\mathrm{M}$. Beckmann writes that K. Fittschen distinguished 9 types of Faustina's portraits, and against the 10 distinguished by him. ${ }^{43} \mathrm{~A}$. Busseni also distinguished 10 types, although not completely identical to Beckmann's types. For example, the last, tenth portrait Busseni dates to $167 \mathrm{AD},{ }^{44}$ but Beckmann does not give the issue a specific date. One recalls that in $\mathrm{BMC}^{45}$ the issue is dated to $168-169$. In general, Busseni gives the chronology of the portrait

39 Butcher K., Ponting M. 2020. The Metallurgy of Roman Silver Coinage: From the Reform of Nero to the Reform of Trajan, First paperback edition, Cambridge University Press, p. 7.

40 E. g. Abdy R. 2014, Chronology...

41 Busseni A. 2019. La monetazione imperiale di Faustina II - Storia, caratteristiche, tematiche, cronologia. This is a work published in an electronic version on the academia.edu portal, available at least from November 2019 .

42 Ibid, p. 5.

43 Beckmann M. 2021. Faustina..., p. 88, 106.

44 Busseni A. 2019. La monetazione..., p. 69.

45 BMC IV, Introduction, p. CXII types more clearly. Busseni writes that Faustina's filiation on coins disappeared in 152, but it is not a data assolutamente certa. ${ }^{46} \mathrm{M}$. Beckmann writes about the legends FAVSTINAE AVGVSTAE, ${ }^{47}$ and A. Busseni presents a sestertius with just such a legend. ${ }^{48}$ In the work of A. Busseni there is also la sequenza dei figli di Faustina attraverso le monete. ${ }^{49}$ One can only regret that $\mathrm{M}$. Beckmann made such little use of Italian literature (the only work in this language that appears in the bibliography, are the famous I Medaglioni Romani of F. Gnecchi from 1912). He would find many works useful for the theme he has chosen, e.g. studies of coin finds, but also interesting insights. According to one of them, the Roman Empire was a diarchy ruled by an emperor and an empress. ${ }^{50}$ What an interesting comment in the context of the interpretation of the iconography of Faustina's coins!

It is also worth adding a few comments regarding the presence of Faustina's filiation on coins. It has been known since the interwar period that this formula had disappeared before the death of Antoninus Pius. Unfortunately, as M. Beckmann rightly points out, many authors still rely on the opinion derived from the RIC volume from $1930^{51}$ writing that it happened only after the death of Antoninus Pius. It is a viewpoint commonly cited in Polish numismatic literature. This is astonishing, as the issue was already clearly described in BMC volume form $1968 .^{52} \mathrm{M}$. Beckmann writes that Faustina's filiation has disappeared shortly before the death of her father Antoninus in 160,53 and further that this was in the year $157 .{ }^{54} \mathrm{He}$ refers, inter alia, to the work of P. L. Strack dating from 1937, but it is a pity that he did not add that, according to this researcher, it happened in $158 .{ }^{55}$ Once again it would be worth referring to the coins minted in Alexandria.

46 Busseni A. 2019. La monetazione..., p. 31.

47 Beckmann M. 2021. Faustina..., p. 65.

48 Busseni A. 2019. La monetazione..., p. 17.

49 Ibid, p. 107-126. Cf. Beckmann M. 2021. Faustina..., p. 111-113.

50 Perassi C. 2014. Ritratti monetali delle Auguste nel III secolo d. C. Una crisi di genere? [in:] Un confronto drammaticocon il XXI secolo: l'Impero Romano del III secolo nella crisi monetaria. Atti del convegno (Biassono, 9 giugno 2012), Biassono: 206

51 Ibid. p. 3, 191-194.

52 BMC IV, Introduction, p. p. XLIV, CXII.

53 Beckmann M. 2021. Faustina..., p. 8

54 Beckmann M. 2021. Faustina..., p. 52-53.

55 Cf. Szeivert W. 1989. Die Münzprägung der Kaiser Marcus Aurelius, Lucius Verus und Commodus (161-192), Wien 1989 
Among the great absences in the literature quoted by M. Beckmann is also the well-known work by W. Szeivert, devoted to Roman coins from $161-192 .{ }^{56}$ This work includes, among others, clearly presented combinations of individual types of Faustina's hairstyles with various types of reverse, in addition for different denominations. ${ }^{57}$ Szeivert also writes about the organization of the $\operatorname{mint}^{58}$ and presents the chronology of the coins, taking into account the types of hairstyles and the types of reverses. ${ }^{59}$

M. Beckmann does not deal with the chronology of Faustina's posthumous coins, but only briefly mentions them. ${ }^{60} \mathrm{He}$ states that This coinage did not last as long as that issued in the name of her deceased mother, Faustina the Elder, and was perhaps concluded within a year of Faustina's death.$^{61}$ It is a pity that he did not check the relevant date, or give a source for this statement. Perhaps in the chronology of the posthumous coins of Faustina the Younger there could be a similar principle to that of her mother Faustina the Elder, that portraits with a veil appeared earlier, closer to her death, and those without the veil later. It would also have been worth checking whether some posthumous coins of Faustina II (e.g. type RIC III 744) were not minted during the independent reign of Commodus in parallel with the posthumous issues of Marcus Aurelius. A manifestation of the 'custom' of honoring both deceased parents by the new emperor, was the aurei issued by Hadrian bearing the legend DIVIS PARENTIBVS, and the closest analogy Sabina's denarii (RIC II 422c), minted after Hadrian's death ${ }^{62}$ or the coins of Faustina I minted after the death of Antoninus Pius. ${ }^{63}$ The argument could be the stylistics of the coins (maybe also metrology?) and the similarity of Faustina II's representations on denarii of this type to some of Crispina's portraits as well as Lucilla and Crispina's hairstyles imitating the hairstyle of the deceased Faustina. ${ }^{64}$ It is easy to guess why the author did not write about Faustina's posthumous coins, because the content placed on these coins did

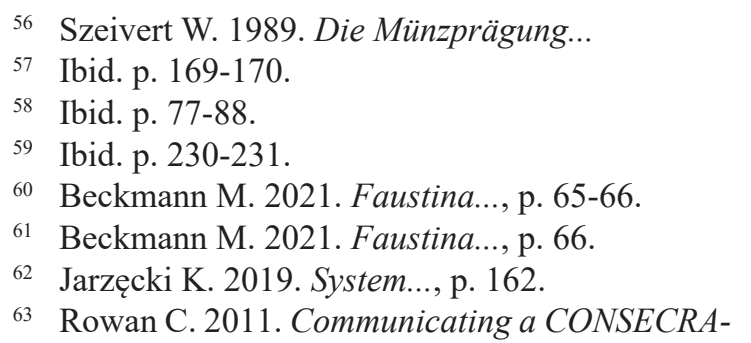
TIO: The deification coinage of Faustina I [in:] Proceedings of the XIVth International Numismatic Congress Glasgow 2009, Glasgow, p. 995.

${ }^{64}$ Jarzęcki K. System..., p. 159. not depend on her anymore. This much is obvious. At the same time, he deprived himself of the opportunity to write important things about Faustina, about the environment with which she was inseparably connected. Who knows if the issues concerning her funeral, cult and coinage (which had many original elements) were not specified by herself in her will?

One of the conclusions that can be expected from such a work is information on what, apart from the iconography, coins bearing the portrait of Faustina II differed from contemporary coins issued by her male counterparts. This work shows that the quantity was different, but yet there are many other differences ${ }^{65}$ which the author does not mention. Pointing out these differences would supply important information about Faustina, her role and activity.

In summing up the work of M. Beckmann, its great advantage lies in the tables showing the connections of coin dies. Its biggest disadvantage is their composition, because the same information could be presented much more clearly, as is the case in the work of W. Szeivert or of the amateur A. Busseni, which the author does not know of, or does not cite for incomprehensible reasons. Another disadvantage is the lack of erudition, not on the part of the author, because he is a valued researcher. Faustina's coinage could be presented in a broader context, allowing for its better understanding. The work should be a source not only of information, but also of inspiration to ask new questions, which could perhaps be answered with data about die connections. The author has conducted interesting research which is well worth getting acquainted with, but the results obtained do not significantly change the current state of knowledge about Faustina's coinage, nor its detailed chronology, it rather is above all an interesting exposition of what was known already. It is hard to expect that they will have a significant influence on the content of the future RIC volume covering these coins. It is worth buying this book and studying it, but it is not to be treated as if it were a groundbreaking treatment, but rather as a voice in a discussion that is still far from over. As you can see, research on the coins of Faustina the Younger is still more on the long and winding road.

Krzysztof Jarzęcki ORCID 0000-0002-4137-9729

The Leon Wyczótkowski District Museum in Bydgoszcz krzysztof.jarzecki@gmail.com 